\title{
Suitability of two root-mining weevils for the biological control of scentless chamomile, Tripleurospermum perforatum, with special regard to potential non-target effects
}

\author{
H.L. Hinz ${ }^{1 *}$ and H. Müller-Schärer ${ }^{2}$ \\ ${ }^{1}$ CABI Bioscience Centre Switzerland, Rue des Grillons 1, CH-2800 \\ Delémont, Switzerland: ${ }^{2}$ University of Fribourg, Department of \\ Biology/Ecology, Pérolles, CH-1700 Fribourg, Switzerland
}

\begin{abstract}
The biology and host range of the two root-mining weevils Diplapion confluens Kirby and Coryssomerus capucinus (Beck), two potential agents for the biological control of scentless chamomile Tripleurospermum perforatum (Mérat) Laínz, were studied in the field in southern Germany and eastern Austria, and in a common garden and under laboratory conditions in Delémont, Switzerland from 1993 to 1999. Both weevils were univoltine, and females started to lay eggs in early spring. Diplapion confluens had three and C. capucinus five instars. Larvae of both species were found in the field from mid-April until the end of July; later instars preferentially fed in the vascular cylinder of the shoot base, root crown or root. Although larvae of both species occupy the same temporal and spatial niche within their host plants, they occurred at all investigated field sites together, and showed a similar distribution within sites. No negative or positive interspecific association was detected. Host-specificity tests including no-choice, single-choice, and multiple-choice tests under confined conditions, as well as tests under field conditions with natural and augmented insect densities revealed that both herbivores were specific to plant species in the tribe Anthemideae. However, their development to mature larva or adult on several cultivated plants, as well as on one plant species native to North America, rendered them unsuitable for field release in North America. It was concluded that to investigate non-target effects reliably, host-specificity tests with biological control agents should be carried out under a variety of conditions, particularly with augmented insect densities, as are expected to occur naturally after release.
\end{abstract}

\section{Introduction}

Scentless chamomile (= scentless mayweed), Tripleurospermum perforatum (Mérat) Laínz (= Matricaria perforata Mérat) (Asteraceae) is an annual, biennial or short lived perennial of European origin that was introduced into North America at the end of the 19th century (Woo et al., 1991). There are two cytotypes, a diploid and a tetraploid.

* Fax: 0041324214871

E-mail : h.hinz@cabi-bioscience.ch
The tetraploid cytotype in particular became a serious weed of cultivated land in the prairie provinces of Alberta, Saskatchewan and Manitoba (Douglas et al., 1991, 1992; Cole, 1994). Because chemical and mechanical control measures often prove to be ineffective or uneconomic (McClay, 1989; Ali, 1995), scentless chamomile was proposed as a target for a classical biological control project in 1988 (Peschken et al., 1990).

Studies on potential biological control agents started in 1990 at the CABI Bioscience Centre Switzerland, in Delémont. Three insect species, the seed-feeding weevil 
Omphalapion hookeri Kirby (Coleoptera: Apionidae), the shoot-mining weevil Microplontus edentulus (Schultze) (Coleoptera: Curculionidae), and the midge Rhopalomyia n. sp. (Diptera: Cecidomyiidae) that produces galls in various meristematic tissues have been introduced to Canada to date (Peschken \& Sawchyn, 1993; Hinz, 1998; Hinz \& McClay, 2000). Because the root was the only part of the plant still unoccupied by natural enemies in its area of introduction, work started in 1993 on the two root-feeding weevil species Diplapion confluens Kirby (Coleoptera: Apionidae), and Coryssomerus capucinus (Beck) (Coleoptera: Curculionidae).

Diplapion confluens has previously been referred to as Apion confluens Kirby, until Ehret (1990) and Alonso-Zarazaga (1990) raised the former subgenus Diplapion to genus level. Basic data on the life history and host range of $D$. confluens and C. capucinus are given by Dieckmann $(1972,1977)$. He recorded $D$. confluens from Matricaria spp. and Anthemis spp., and C. capucinus from several species in the tribe Anthemideae, including Tripleurospermum perforatum, Anthemis tinctoria L., Achillea millefolium L., Tanacetum parthenium (L.) Schultz.-Bip. and Leucanthemum vulgare Lam. Diplapion confluens is present but usually rare throughout Europe and the Near East; and C. capucinus is reported to be present but not common in Europe and eastern North Africa (Dieckmann, 1972, 1977). At high densities, C. capucinus was observed to stunt plants and provoke premature senescence (Bacher, 1994), while D. confluens was observed to kill shoots at densities of about 80 larvae per plant (personal observation). The quantitative impact of $D$. confluens and C. capucinus alone and in combination with wheat competition on their host plant is reported elsewhere (Hinz, 1999).

To evaluate the safety and suitability of these two rootherbivores as biological control agents for scentless chamomile, the biology and host specificity of $D$. confluens and $C$. capucinus were investigated at field sites in southern Germany and eastern Austria, and in the garden and the laboratory at the CABI Bioscience Centre, Switzerland, in Delémont from 1993 to 1999 . We contrast the biology and host range of the two species, relate their life histories to the phenology of scentless chamomile, and compare our results with the data already available for $D$. confluens and $C$. capucinus. Special emphasis is placed on potential non-target effects of the two species and the likelihood of interspecific competition is discussed.

\section{Materials and methods \\ Biology and life history}

\section{Laboratory studies}

To estimate fecundity (the total number of eggs laid by a female during her life), one newly emerged (C. capucinus) or one overwintered (D. confluens) weevil pair was placed into each of seven transparent plastic cylinders (160 mm height, $110 \mathrm{~mm}$ diameter) from mid-March 1994 onwards. Small rosettes of scentless chamomile, or cut shoots, with some roots attached were inserted in a moist piece of florist sponge enclosed in plastic foil. Every three days, the plant material was dissected for eggs and the weevils were provided with fresh plants. This was carried on throughout the lifespan of the insects, i.e. until the end of August 1994. The cylinders were kept outside, beneath a shelter. Differences in fecundity and oviposition period between the two species were analysed using independent samples ttests.
To study the effect of different temperatures on the duration of embryogenesis and on fertility (the proportion of eggs laid that eclosed), 10-25 eggs obtained in the fecundity study were placed on moist filter paper in a closed Petri dish (13 $\mathrm{mm}$ high, $50 \mathrm{~mm}$ diameter). Three to four dishes were incubated at each of five constant temperatures $(12.5,15$, $17.5,20$ and $25 \pm 1{ }^{\circ} \mathrm{C}$ ). The light regime was set to $16 \mathrm{~L}: 8 \mathrm{D}$. Hatched larvae were counted daily and then removed.

\section{Garden studies}

Studies using potted plants of T. perforatum were carried out in the garden at the CABI Bioscience Centre, Switzerland, in Delémont $\left(47^{\circ} 21^{\prime} \mathrm{N}, 7^{\circ} 22^{\prime} \mathrm{E}\right)$. Seventy to 140 root systems of scentless chamomile containing mature larvae or pupae of D. confluens and/or C. capucinus were collected each year from 1993 to 1997 from different field sites in the Rhine Valley, Germany (see field studies for details), between the end of June and mid-July. These were used to start a colony at the Centre, follow adult emergence and estimate rates of parasitism. Between 1 and 30 root systems, depending on size, were transferred together into black 351 plastic bags. A plastic tube (18 $\mathrm{mm}$ diameter), ending in a transparent plastic cup $(80 \mathrm{~mm}$ high, $70 \mathrm{~mm}$ diameter) was attached to each bag. The bags were kept outside, underneath a shelter. Emerging weevils as well as parasitoids were collected from the plastic cups every one to two days. Because D. confluens adults emerge during summer, but only start to lay eggs the following spring, adults were overwintered on potted rosettes of scentless chamomile, which were covered with a gauze bag and placed outside. After overwintering (D. confluens) or after emergence in spring (C. capucinus), adults were transferred onto potted plants of T. perforatum covered with gauze. Once mature larvae or pupae were present, the root systems and soil were transferred into collection traps as described above.

To investigate the duration of larval development and pupation, 10-15 newly hatched first instars each of D. confluens or C. capucinus were transferred onto 40 T. perforatum plants between the end of April and mid-May 1993. The plants were embedded in a garden bed, one to two plants each were dissected at about weekly intervals, and the number and developmental stages of individuals found were recorded.

To estimate at which depth C. capucinus larvae pupate and adults overwinter, the root system and attached soil of infested scentless chamomile plants were separated into three layers $(0-4,4-8,8-12 \mathrm{~cm})$ in autumn 1997. All material was transferred separately into emergence traps (as described above), which were placed beneath a shelter during winter and checked for adult emergence in spring 1998.

\section{Field studies}

Investigations on the phenology and ecology of $D$. confluens and C. capucinus were carried out from 1993 to 1997 in the Rhine Valley near Neuenburg $\left(47^{\circ} 48^{\prime} \mathrm{N}, 7^{\circ} 36^{\prime} \mathrm{E}\right)$ at sites with natural populations of T. perforatum, and the two weevil species. Over the whole study period, a total of seven field sites, within about $5 \mathrm{~km}$ of each other, were sampled. Five of the sites were fallow fields (N1-4 and N6), the two other sites were dumps (N5 and N7). Each year, different sites were sampled, because scentless chamomile is outcompeted by perennials within one to two years. 
To investigate the occurrence of adults of D. confluens and C. capucinus in the field, scentless chamomile plants were regularly swept or, alternatively, searched for weevils, if plants were still in the rosette stage, for about $15 \mathrm{~min}$ per site by two people.

To follow the phenology and abundance of immature stages and their distribution in the plant, 5-25 plants were dug up per site, approximately twice per month between April and July 1993 to 1996. Plant samples were taken at equal intervals along two transects across each site. Care was taken to include plants of different sizes. The plants were dissected under a stereo microscope and the number and location of developmental stages of the insects found were noted. The proportional overlap between the different instars of the two species within plants was calculated using the formula:

$$
\mathrm{O}_{i j}=1-0.5 \sum_{h=1}^{n} p_{i h}-p_{j h}
$$

where $\mathrm{O}_{i j}$ is the proportional overlap of the two species, $p_{i h}$ and $p_{i h}$ are the proportions of species $\mathrm{i}$ and $\mathrm{j}$ in resource category $h$, and $n$ is the total number of resource categories (Southwood, 1978). In this study, six resource categories were distinguished: (i) the leaf or leaf base; (ii) the shoot base (cortex); (iii) the shoot base (vascular cylinder); (iv) the root crown and root (cortex); (v) the root crown and root (vascular cylinder); and (vi) the soil. The index $(\mathrm{O})$ varies from 1 (complete overlap) to 0 (no overlap).

Plant biomass (dry weight of above- and below-ground plant parts) was measured to relate plant size to the number of individuals of D. confluens or C. capucinus (eggs, larvae, and pupae) found per plant. To obtain normally distributed residuals, the number of individuals was square-root and plant biomass $\log _{10}$-transformed.

\section{Host range}

Host specificity tests were carried out with $D$. confluens from 1993 to 1999, and with C. capucinus from 1993 to 1995. The original test plant list (Peschken \& Sawchyn, 1993) was modified to include a total of 43 plant species and cultivars in six tribes of the Asteraceae (appendix 1). It contained plant species that are: (i) closely related to scentless chamomile; (ii) recorded as hosts of the two weevils in the literature (Dieckmann, 1972, 1977); (iii) commercially grown in North America and/or Europe; and (iv) native to North America. Only results of 15 test plant species within the tribe Anthemideae will be presented (see table 3 ), because preliminary tests with $D$. confluens and C. capucinus showed that species outside the tribe Anthemideae were either not accepted for oviposition, or no signs of larval mining were found (see appendix 1, and H.L. Hinz, unpublished data). In addition, C. capucinus proved to be too polyphagous early on, and tests were stopped with this species before completion of the test plant list. Therefore, more tests were carried out with $D$. confluens than with $C$. capucinus. All weevils used in the tests were either collected in the Rhine Valley, or were from subsequent rearings at the Centre. Plants used in tests were either dissected for attack and/or root systems were kept in collection traps (see above) or under gauze covers for adult emergence.

It was not possible to distinguish visually the sex of live $D$. confluens used in the tests. However, through previous dissections of dead weevils, the sex ratio of $D$. confluens was determined to be about $1.1: 1.0$ (females : males, $\mathrm{n}=160$ ). In addition, we ensured beforehand that the $D$. confluens used in the no-choice and single-choice tests were laying eggs by offering them cut shoots of scentless chamomile in cylinders (for details see laboratory studies).

\section{No-choice tests with D. confluens}

Between 4 April and 17 May 1997, no-choice development tests were set up with $D$. confluens with 18 test plant species on which oviposition had occurred in previous tests (see appendix 1). Six to eight adults each were released for about two weeks onto individual potted test or T. perforatum control plants covered with a gauze bag. Each time a series of test plants was set up, one to five control plants were set up as well. Three to four replicates were made per test plant species. During exposure, the plants were kept outside in an insectary. Afterwards they were placed in a garden bed.

\section{Single-choice tests with $\mathrm{D}$. confluens}

In 1996, single-choice development tests were set up with D. confluens with two, and in 1998 with nine test plant species, on which development had occurred in no-choice tests. Between 24 April and 16 May, one test plant and one T. perforatum (control) plant were potted together, covered with a gauze bag, and eight to ten $D$. confluens adults each released for about six (1996) or three (1998) weeks. Two to four replicates were set up per test plant species. During exposure, the plants were kept outside in an insectary. Afterwards they were placed in a garden bed.

\section{Multiple-choice tests with $\mathrm{D}$. confluens and $\mathrm{C}$. capucinus}

Field cage. This test was only done with D. confluens. A gauze-covered field cage $(2 \times 2 \times 2 \mathrm{~m})$ was set up on 26 April 1993 in the Centre's garden, and one plant each of 12 test species was exposed for about eight weeks to $40 \mathrm{D}$. confluens adults. On 1 May 1995, a similar field cage was set up and two plants each of nine test species were exposed for about six weeks to $76 \mathrm{D}$. confluens adults. In each cage, an equal number of $T$. perforatum control plants was offered.

Open field with natural weevil densities. Four open field tests were established at field sites in the Rhine Valley and in eastern Austria, on which D. confluens and/or C. capucinus were known to occur: two in 1993 with 18 test plant species each, one in 1994 with 15 test plant species and one in 1995 with six test species. Groups of plants, each consisting of two potted individuals of one test plant species and two potted T. perforatum control plants were planted in a distance of $2-3$ $m$ from each other. In 1993, single test plants were randomly distributed together with four control plants at each field site. After about six weeks the plants were taken back to Delémont.

Open field with augmented weevil density. This test was only done with $D$. confluens. It has been argued that agent densities at natural field sites in the area of origin may not be high enough to investigate non-target effects reliably (McFadyen, 1998; Briese, 1999). Therefore, an open field test was set up in the garden of the Centre in 1999, and a known number of $D$. confluens adults was released. Five potted plants each of seven test species, and tetraploid T. perforatum originating from Europe and Canada were embedded in sawdust in a wooden frame $(2 \times 2 \mathrm{~m})$. The plants were arranged in a completely randomized block. On 30 April, 10 D. confluens adults were released onto each plant. After ten weeks, the test was terminated. 
Field host range of $\mathrm{D}$. confluens and $\mathrm{C}$. capucinus

Natural field sites. From 1993 to 1995, between the beginning of June and the beginning of July (i.e. at a time when mature larvae or pupae of both weevil species are present), test plant species growing intermixed with scentless chamomile at field sites at which both or one of the two weevil species occurred were sampled in the Rhine Valley or in eastern Austria. Whenever available, plants of T. perforatum were sampled as controls. Root stocks were either transferred into collection traps for adult emergence, or dissected for signs of attack. The following plant species were sampled (numbers given in brackets indicate the total number of plants sampled and the number of sites): Matricaria recutita L.(80/1), M. discoidea DC (10/1), Anthemis tinctoria (13/2), Artemisia vulgaris L. (27/3), Achillea millefolium (20/2), Leucanthemum vulgare (5/1), and Erigeron annuus (L.) Pers. $(5 / 2)$.

Commercial fields. In addition, 20-40 plants each were sampled from three commercial fields of the herbal chamomile, $M$. recutita, in Switzerland (near Basel) and in eastern Austria in 1997 and 1998, and 10-12 plants each from three commercial fields of sunflowers, Helianthus annuus L., in the Rhine Valley and in eastern Austria in 1995 and 1998.

\section{Results \\ Adult phenology}

Detailed descriptions of the adult morphology of both species, including sex differences, are given by Dieckmann $(1972,1977)$ and Lohse (1983). In the Rhine Valley, adults of both species were detected as early as 10 March on scentless chamomile plants, but most weevils were found during April and May. Diplapion confluens adults found from July onwards probably belonged to the F1-generation. In contrast to Dieckmann (1972), who observed D. confluens through to October, we did not find either species in autumn.

At the Centre, D. confluens adults started to emerge from dug up root stocks at the beginning of July (fig. 1A). Most adults emerged from the end of July until the beginning of August. The time until 50\% of adults had emerged differed by two and a half weeks between locations (year and site of sampling) (fig. 1A). During overwintering on potted rosettes, males and females of $D$. confluens stayed in the leaf litter, but were active and feeding whenever temperatures were above about $10^{\circ} \mathrm{C}$. At the Centre, between 20 and $25 \%$ of adults died during overwintering. Adults of the F1generation of $C$. capucinus hibernated in the soil and emerged the following spring, mainly during March (fig. 1B). The time until $50 \%$ of adults had emerged differed by less than a week between locations. For both species, the sex ratio was slightly in favour of females, $1.13: 1(n=160)$ for D. confluens, and 1.14: $1(\mathrm{n}=505)$ for $C$. capucinus. The mortality of adults of both species increased in June after the oviposition period.

\section{Oviposition and fecundity}

The eggs of $D$. confluens are yellow to orange in colour, and smaller and rounder than the creamish to white, oval shaped eggs of $C$. capucinus (table 1 ). In plants sampled in the field, eggs of D. confluens were found from April until the beginning of July (fig. 2), mostly in the root or root crown of

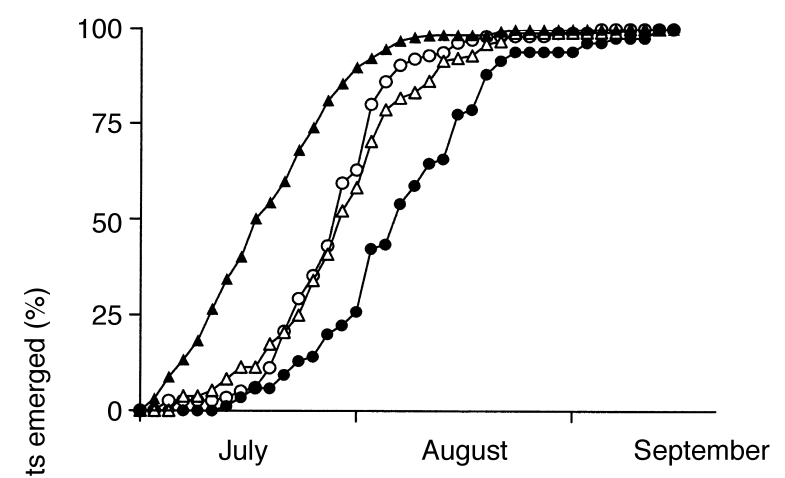

B

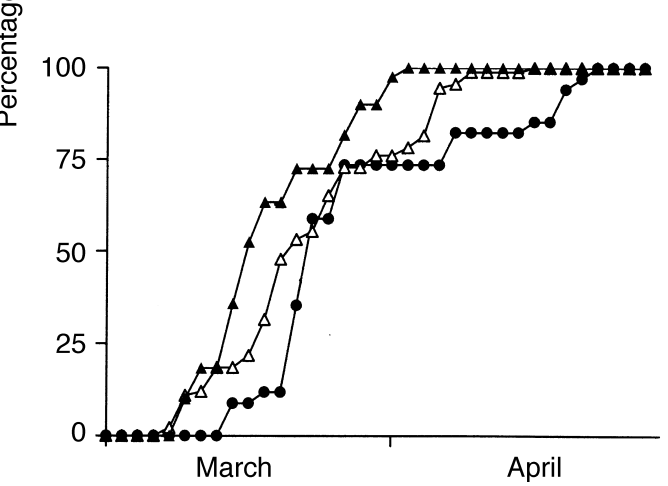

Fig. 1. Cumulative emergence of adults of (A) Diplapion confluens and (B) Coryssomerus capucinus at the CABI Bioscience Centre Switzerland from root stocks collected in different years and at various field sites (locations) in the Rhine Valley, Germany. $\mathbf{\Delta}$, Site N5, $1994(579,120) ; \Delta$, site N6, 1995 (132, 100); $\bullet$, site N7, $1996(85,34) ;$, site N7, 1997 (116). For details of field sites see Materials and methods. Numbers in parenthesis indicate the total number of individuals of $D$. confluens and $C$. capucinus, respectively, emerged.

scentless chamomile (fig. 3A), and eggs of C. capucinus from April until the beginning of June (fig. 2), mostly in the leaf base of the lowest leaf (fig. 3B). Our observations differed from those of Dieckmann (1972) that C. capucinus lays its eggs into the root crown. All eggs were laid singly.

At the Centre, females of $C$. capucinus fed for about three weeks after emergence before laying eggs. Because D. confluens emerged in summer and overwintered as an

Table 1. Egg size and head capsule diameters (mean \pm SE) of different instars of Diplapion confluens and Coryssomerus capucinus.

\begin{tabular}{lcc}
\hline Stage & D. confluens & C. capucinus \\
\hline Egg length & $0.49 \pm 0.005(\mathrm{n}=49)$ & $0.66 \pm 0.008(\mathrm{n}=43)$ \\
Egg width & $0.31 \pm 0.003(\mathrm{n}=49)$ & $0.33 \pm 0.006(\mathrm{n}=43)$ \\
1st instar & $0.21 \pm 0.002(\mathrm{n}=82)$ & $0.23 \pm 0.001(\mathrm{n}=113)$ \\
2nd instar & $0.32 \pm 0.002(\mathrm{n}=98)$ & $0.34 \pm 0.003(\mathrm{n}=113)$ \\
3rd instar & $0.47 \pm 0.002(\mathrm{n}=239)$ & $0.48 \pm 0.003(\mathrm{n}=181)$ \\
4th instar & & $0.70 \pm 0.003(\mathrm{n}=214)$ \\
5th instar & & $0.93 \pm 0.004(\mathrm{n}=211)$ \\
\hline
\end{tabular}

All measurements in $\mathrm{mm}$. 
D. confluens

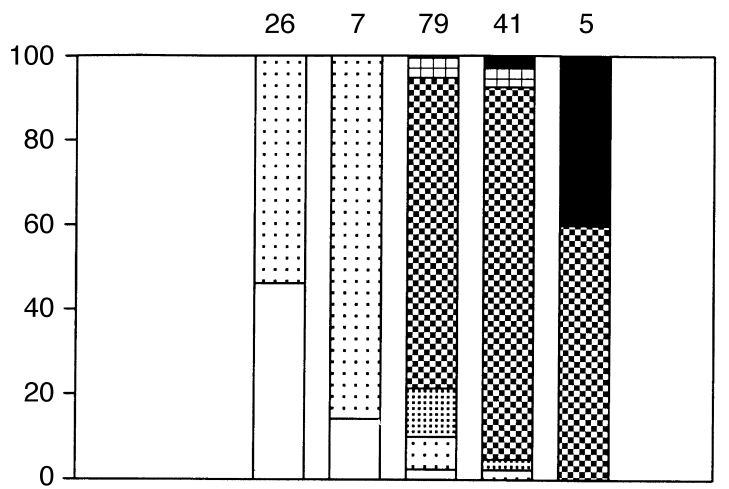

C. capucinus

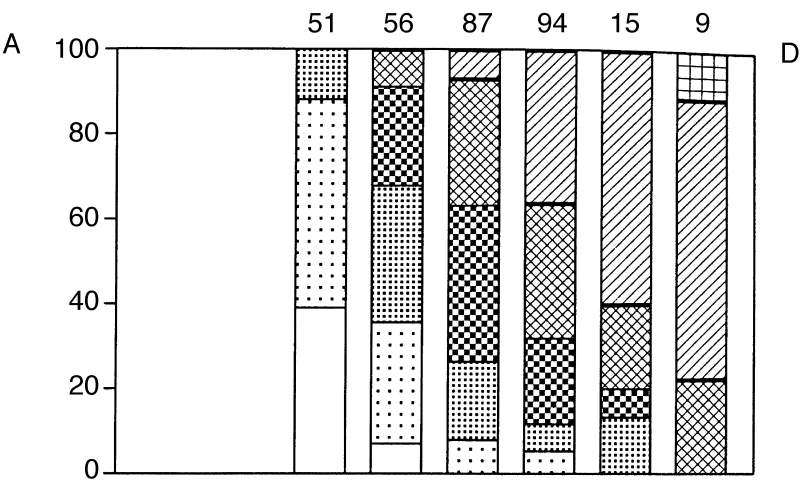

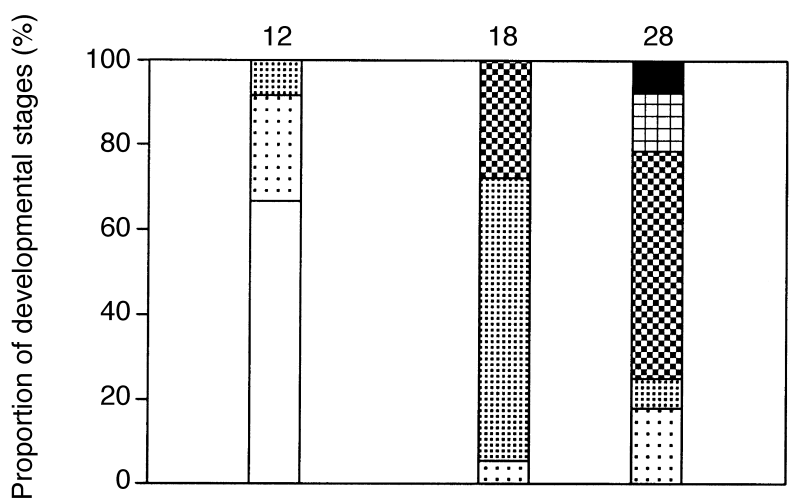

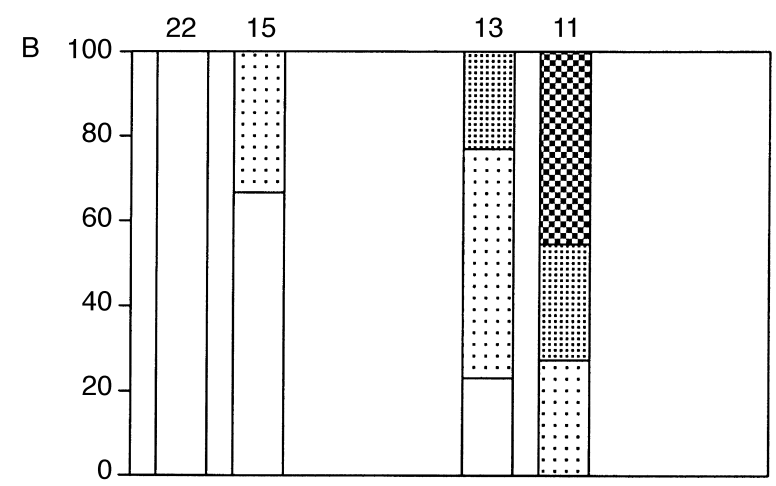

E
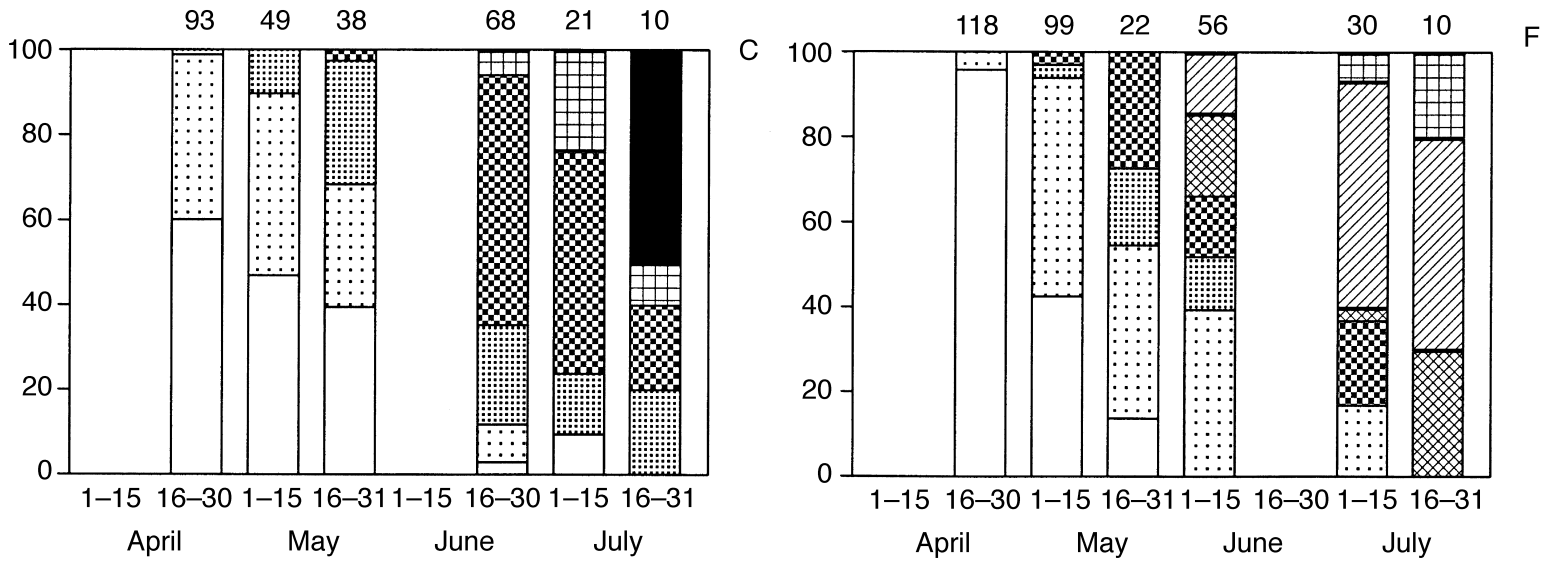

Fig. 2. Phenology of Diplapion confluens and Coryssomerus capucinus in the Rhine Valley, Germany, between 1993 and 1996 . (A) + (D), sites N1-3, 1993; (B), site N5, 1994; (E), site N4, 1994; (C) + (F), site N6, 1996. For details of field sites see Materials and methods. Total

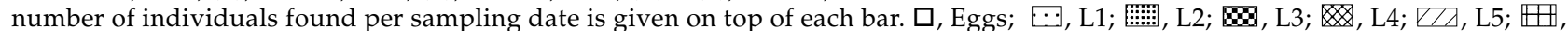
pupae; $\mathbf{\square}$, adults.

adult, it was not possible to estimate a comparable preoviposition period. Under laboratory conditions, the oviposition period of both species lasted from the end of March until the end of August. Females of D. confluens laid an average of $1.1 \pm 0.15$ (SE) eggs per day, resulting in a mean of $120 \pm 14$ (range 77-183) eggs per female over an oviposition period of $110 \pm 8.8$ days. Coryssomerus capucinus females laid on average $0.75 \pm 0.12$ eggs per day or $84 \pm 23$ (range 42-192) eggs per female over an oviposition period of $100 \pm 17$ days. Neither fecundity $(t=0.36$, d.f. $=12, P=$ 
$0.729)$, nor the duration of the oviposition period $(t=-0.68$, d.f. $=12, P=0.515)$ differed significantly between the two species. The oviposition period at the Centre was presumably longer than in the field, because plants suitable for oviposition were offered continuously. However, the release of ovipositing adults of D. confluens at the beginning of June onto potted T. perforatum plants did not result in the production of viable offspring. Larvae developed to second or third instar until late summer, but no adults emerged. Although copulations of $D$. confluens were observed after emergence in summer, oviposition never occurred.

\section{Development and feeding sites of immature stages}

Diplapion confluens needed 99.4 degree days to complete egg development, and C. capucinus needed 75.2 degree days. For both species, fastest egg development occurred at $25^{\circ} \mathrm{C}$ (D. confluens: $6.2 \pm 0.05$ days (range 6-7); C. capucinus: $5.0 \pm 0.03$ days (range 4-6)). No egg development occurred at constant $12.5^{\circ} \mathrm{C}$. Within the temperature range of $14-25^{\circ} \mathrm{C}$, the hatching rate of larvae (fertility) was not significantly correlated with temperature in either species, and varied between $60-80 \%$ for D. confluens and $75-86 \%$ for C. capucinus.

Diplapion confluens has three, and C. capucinus five instars (table 1). Larvae of the two species can easily be distinguished, because those of $C$. capucinus have two distinct bristles at the end of their abdomen (Dieckmann, 1972). The instars within each species can be distinguished by differences in head capsule diameters (table 1).

Larvae of both species were found from mid April until the end of July in the field (fig. 2). However, the proportion of mature larvae still present in July was higher for $C$. capucinus than for D. confluens (fig. 2), indicating that $D$. confluens develops faster. This was confirmed by results of the garden study, in which the development from egg to adult took about 70-80 days for $D$. confluens, and 100-110 days for C. capucinus. In both species the last instar had the longest development time.

The within-plant distributions of first instar larvae reflect the different oviposition behaviours of the two species: while the majority of first instars of $D$. confluens mined in the cortex of the root and root crown, most first instars of $C$. capucinus were found in the shoot base or in the leaf base of the lowest leaves (fig. 3). The proportional niche overlap of first instars was calculated as $\mathrm{O}=0.42$, indicating low to moderate levels of overlap. Later instars of $D$. confluens and C. capucinus mined in the vascular cylinder of the shoot base, root crown or root, with a maximum proportional niche overlap between third instars of $D$. confluens and fourth instars of C. capucinus of $\mathrm{O}=0.79$. Aggressive behaviour between larvae was never observed. Mature larvae of $D$. confluens excavated pupation chambers inside the plants, mainly in the vascular cylinder of the root crown, while most mature larvae of $C$. capucinus left the plant to feed on the root cortex from the outside and to pupate in the soil. Thus, the proportional niche overlap between third instars of $D$. confluens and fifth instars of $C$. capucinus was reduced to $\mathrm{O}=0.40$. The observation that $D$. confluens attack causes a gall-like swelling of the root crown (Dieckmann, 1972) was not observed by us.

On potted plants of scentless chamomile, $24.5 \pm 4.8 \%$ of

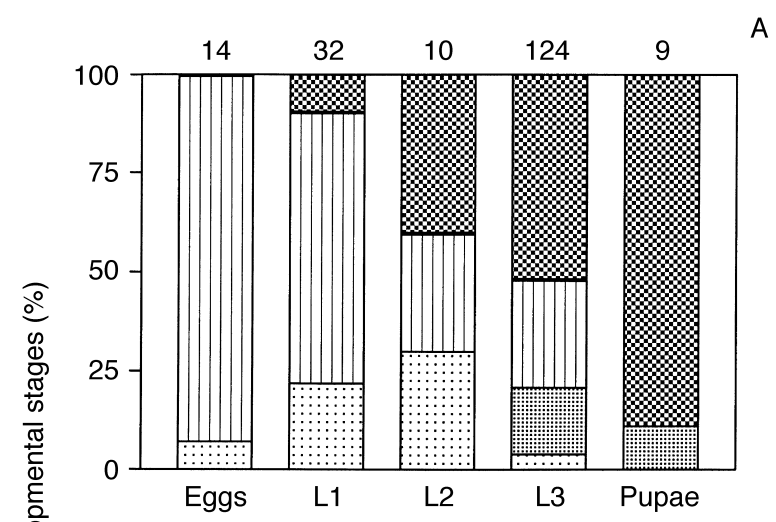

A

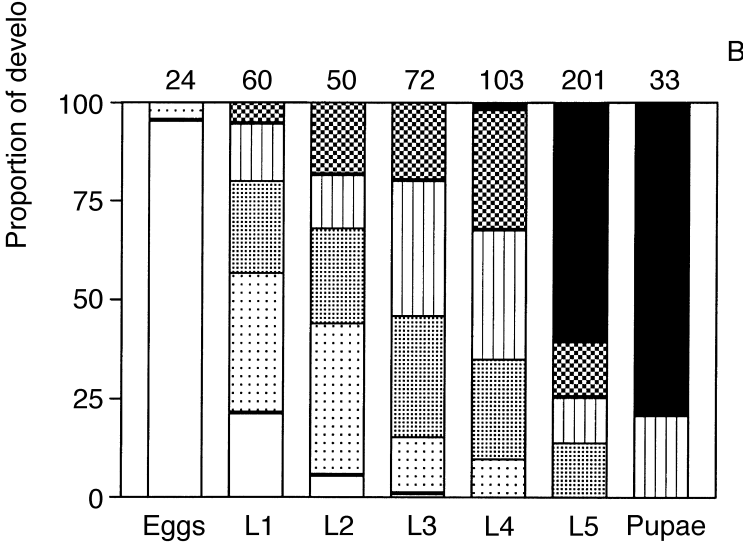

Fig. 3. Distribution of various developmental stages of (A) Diplapion confluens and (B) Coryssomerus capucinus within plants. Data are from dissection of Tripleurospermum perforatum plants collected on seven occasions between 4 May and 30 July 1993 at each of three field sites (N1-3) in the Rhine Valley, Germany. Total number of individuals found is given on top of each bar.

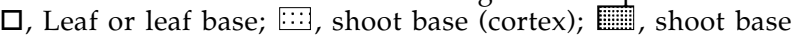
(vascular cylinder); $\square$, root crown and root (cortex); $\mathbb{\otimes}$, root crown and root (vascular cylinder); $\mathbf{E}$, soil.

pupae and adults of $C$. capucinus were found close to the root in the top $0-4 \mathrm{~cm}$ soil layer, $59.3 \pm 4.2 \%$ between 4 and $8 \mathrm{~cm}$, and $16.1 \pm 5.9 \%$ at a soil depth of $8-12 \mathrm{~cm}(\mathrm{n}=233)$.

\section{Attack rates and distribution in the field}

The two species occurred together at most field sites investigated (table 2). The percentage of plants attacked by $D$. confluens in the field varied from 0 to $70 \%$. The highest average number of larvae found per attacked plant was 10.4, and the highest number of larvae found in one plant was 43 . The percentage of plants attacked by $C$. capucinus varied from 45 to $100 \%$. The highest average number of larvae per attacked plant was 14.3, and the highest number of larvae found in one plant was 24. Usually, more individuals of D. confluens than of C. capucinus were found in the root stocks (table 2).

The number of immature and mature stages of $D$. confluens and of $C$. capucinus were positively correlated with plant biomass $(D$. confluens: eggs and first instars; $r=0.55, P<0.01$, $\mathrm{n}=20$; mature larvae and pupae, $r=0.81, P<0.001, \mathrm{n}=16 ; C$. capucinus: eggs and first instars; $r=0.58, P<0.001, \mathrm{n}=39$; mature larvae and pupae, $r=0.82, P<0.001, n=26$ ).

The size of attacked and unattacked plants could only be 
Table 2. Proportion of plants attacked by Diplapion confluens and Coryssomerus capucinus and mean attack rate per plant for different samples of Tripleurospermum perforatum from the Rhine Valley.

\begin{tabular}{|c|c|c|c|c|c|c|c|c|c|}
\hline \multirow{2}{*}{\multicolumn{2}{|c|}{ Site/Sample }} & \multirow[t]{2}{*}{$\begin{array}{l}\text { No. of } \\
\text { plants } \\
\text { examined }\end{array}$} & \multirow[t]{2}{*}{$\begin{array}{c}\text { Mean } \\
\text { number of } \\
\text { shoots per } \\
\text { plant } \pm \text { SE }\end{array}$} & \multicolumn{2}{|c|}{$\begin{array}{l}\text { Percentage of plants } \\
\text { attacked }\end{array}$} & \multicolumn{2}{|c|}{$\begin{array}{l}\text { Total number of larvae } \\
\text { found upon dissection or } \\
\text { number of adults emerged }\end{array}$} & \multicolumn{2}{|c|}{$\begin{array}{c}\text { Mean number of } \\
\text { individuals per attacked } \\
\text { plant }( \pm \text { SE) }\end{array}$} \\
\hline & & & & D. confluens & C. capucinus & D. confluens & С. сарисіпиs & D. confluens & C. capucinus \\
\hline N1 & 4 June 1993 & 8 & $4.4 \pm 1.5$ & 62.5 & 62.5 & 52 & 41 & $10.4 \pm 3.4$ & $8.2 \pm 2.1$ \\
\hline N1 & 18 June 1993 & 5 & $8.2 \pm 1.2$ & 60.0 & 100.0 & 23 & 27 & $7.7 \pm 4.2$ & $5.4 \pm 2.8$ \\
\hline N2 & 4 June 1993 & 9 & $3.1 \pm 0.7$ & 66.7 & 77.8 & 32 & 22 & $5.3 \pm 2.8$ & $3.1 \pm 1.7$ \\
\hline N2 & 18 June 1993 & 25 & $1.4 \pm 0.2$ & 48.0 & 44.0 & 16 & 13 & $1.3 \pm 0.2$ & $1.2 \pm 0.1$ \\
\hline N3 & 4 June 1993 & 19 & $2.7 \pm 1.0$ & 0.0 & 57.9 & 0 & 38 & 0.0 & $3.4 \pm 1.6$ \\
\hline N3 & 18 June 1993 & 4 & $10.5 \pm 2.7$ & 50.0 & 100.0 & 2 & 57 & $1.0 \pm 0.0$ & $14.3 \pm 3.6$ \\
\hline N4 & 21 June 1994 & 21 & $1.0 \pm 0.0$ & 14.3 & 47.6 & 4 & 12 & $1.3 \pm 0.3$ & $1.2 \pm 0.1$ \\
\hline N5 & 1-5 July 1994 & 131 & - & - & - & 590 & 208 & $4.5^{\mathrm{a}}$ & $1.6^{\mathrm{a}}$ \\
\hline N6 & 6 June 1995 & 10 & $5.5 \pm 1.0$ & 70.0 & 70.0 & 18 & 17 & $2.6 \pm 1.0$ & $2.4 \pm 0.4$ \\
\hline N6 & 6 July 1995 & 9 & $5.6 \pm 1.1$ & 66.7 & 44.4 & 33 & 10 & $5.5 \pm 2.2$ & $2.5 \pm 0.6$ \\
\hline N6 & 5 July 1995 & 67 & $5.3 \pm 1.2$ & - & - & 110 & 41 & $1.6^{\mathrm{a}}$ & $0.6^{\mathrm{a}}$ \\
\hline N7 & 15 June 1996 & 12 & $5.8 \pm 1.7$ & 58.3 & 83.3 & 66 & 56 & $9.4 \pm 5.7$ & $5.6 \pm 2.1$ \\
\hline N7 & 3 July 1996 & 9 & $4.7 \pm 1.7$ & 44.4 & 66.7 & 22 & 23 & $5.5 \pm 4.2$ & $3.8 \pm 2.3$ \\
\hline N7 & 2-25 July 1996 & 125 & $3.0 \pm 0.3$ & - & - & 66 & 17 & $0.5^{\mathrm{a}}$ & $0.1^{\mathrm{a}}$ \\
\hline
\end{tabular}

${ }^{a}$ Number of adults emerged divided by number of plants.

For description of sites see Materials and methods.

compared for C. capucinus, for which the biomass of plants infested with eggs and first instars was on average 2.5 times higher than that of unattacked plants (8 April 1994; attacked plants: $0.538 \pm 0.191 \mathrm{~g}$; unattacked plants: $0.196 \pm 0.105 \mathrm{~g} ; t$ $=5.07$, d.f. $=18, P<0.001)$. This indicates that females of C. capucinus preferred larger plants for oviposition.

For both species, the slopes of the variance-mean ratios were steeper than the slope of a Poisson distribution $(b=1)$ (D. confluens: $b=1.96, t=3.18$, d.f. $=8, P<0.01 ;$ C capucinus: $b=1.67, t=2.88$, d.f. $=11, P<0.01$ ), which indicates that both species aggregated on individual plants in the field. The regression coefficients did not differ between the two species (ANOVA: $F_{1,18}=2.28, P=0.149$ ). Although the two species showed a similar distribution, and they occurred at all field sites together (see table 2), a $\chi^{2}$-test to measure interspecific association was not significant $\left(\chi^{2}=1.69\right.$, d.f. $=1, P=0.193 ; \mathrm{n}$ =98). Therefore, D. confluens and C. capucinus occurred independently of each other in the field, with neither species avoiding or preferring plants attacked by the other species.

\section{Parasitism}

Only one parasitoid species, Trichomalus sp. near elongatus Delucchi \& Graham (Hymenoptera: Pteromalidae) attacked $D$. confluens larvae in the Rhine Valley. Rates of parasitism ranged from 2.0 to $4.5 \%$. Coryssomerus capucinus was attacked by two parasitoid species, Entedon pseudonigritarsis Erdös (Hymenoptera: Eulophidae) and Triaspis obscurella (Nees) (Hymenoptera: Braconidae). The eulophid wasp emerged each year, and percentage parasitism ranged between 20.5 and $72.7 \%$. The braconid was found only once.

\section{Host range investigations}

Of the 15 plant species for which results are presented, Achillea ptarmica L. did not support larval development of either of the two weevil species (table 3). Achillea millefolium and Tanacetum vulgare L. supported the development of $C$. capucinus, but were not accepted for oviposition ( $A$. millefolium) or did not support the development (T. vulgare) of $D$. confluens. Twelve test plant species supported the development to adult or mature larva of both weevils. However, from Leucanthemum maximum (Ramond) DC only one $D$. confluens adult emerged in no-choice tests, and no attack occurred in single-choice tests (table 3 ). In addition, all plant species tested with $D$. confluens under single-choice conditions, with the exception of $M$. recutita, had significantly lower attack rates than the corresponding control plants (for detailed results see Hinz \& Kirkpatrick, 1998). Tanacetum huronense Nutt. and T. parthenium were attacked to some degree by $D$. confluens in no-choice and single-choice tests but not in multiple-choice tests under field cage or field conditions (table 3 ). In all three test designs (i.e. no, single, and multiple-choice) carried out with Chamaemelum nobile (L.) All. (= Anthemis nobilis L.), only a single D. confluens adult emerged or larva was found (table 3 ). In addition, several dead first instars were found, indicating that $C$. nobile is not a suitable host plant of $D$. confluens.

Of the seven plant species sampled that were growing intermixed with scentless chamomile (field host range), only the closely related Matricaria recutita (see table 4) and $M$. discoidea were attacked by D. confluens and C. capucinus.

Helianthus annuus, sampled at commercial fields, were not attacked by either of the two species.

Diplapion confluens attacked the herbal chamomile, $M$. recutita, to the same extent as $T$. perforatum in no-choice tests and in single-choice tests in 1998 (table 4). In single-choice tests carried out in 1996, scentless chamomile was preferred over the herbal chamomile, though a statistical comparison was not possible, due to the limited number of replicates. Herbal chamomile plants growing intermixed with scentless chamomile at natural field sites, as well as $M$. recutita plants sampled from commercial fields were not attacked or only attacked to a very minor degree (table 4 ). In contrast, $D$. confluens preferred $M$. recutita over scentless chamomile in the open field test in which weevil numbers were augmented. 
Table 3. Results of host-specificity tests conducted with Diplapion confluens and Coryssomerus capucinus from 1993 to 1999 at the CABI Bioscience Centre Switzerland in Delémont and at field sites in the Rhine Valley, Germany, and Eastern Austria (all plant species are in the tribe Anthemideae).

\begin{tabular}{|c|c|c|c|c|c|c|c|c|}
\hline \multirow[t]{3}{*}{ Plant species } & \multicolumn{6}{|c|}{ D. confluens } & \multirow{2}{*}{\multicolumn{2}{|c|}{$\begin{array}{c}\text { C. capucinus } \\
\text { Multiple-choice } \\
(1993-1995)\end{array}$}} \\
\hline & \multicolumn{2}{|c|}{$\begin{array}{l}\text { No-choice } \\
\text { (1997) }\end{array}$} & \multicolumn{2}{|c|}{$\begin{array}{l}\text { Single-choice } \\
(1996+1998)\end{array}$} & \multicolumn{2}{|c|}{$\begin{array}{c}\text { Multiple-choice } \\
(1993+1995+1999)\end{array}$} & & \\
\hline & $\begin{array}{l}\text { No. of } \\
\text { replicates }\end{array}$ & $\begin{array}{c}\text { Attack } \\
\text { level }\end{array}$ & $\begin{array}{l}\text { No. of } \\
\text { replicates }\end{array}$ & $\begin{array}{c}\text { Attack } \\
\text { level }\end{array}$ & $\begin{array}{l}\text { No. of } \\
\text { replicates }\end{array}$ & $\begin{array}{c}\text { Attack } \\
\text { level }\end{array}$ & $\begin{array}{l}\text { No. of } \\
\text { replicates }\end{array}$ & $\begin{array}{l}\text { Attack } \\
\text { level }\end{array}$ \\
\hline Tripleurospermum perforatum (control) & 17 & ++ & 40 & ++ & 54 & ++ & 48 & ++ \\
\hline T. maritimum & - & - & - & - & 2 & ++ & 3 & ++ \\
\hline Matricaria recutita & 4 & ++ & 6 & ++ & 9 & ++ & 1 & ++ \\
\hline M. discoidea & 3 & ++ & - & - & 3 & ++ & 4 & + \\
\hline Anthemis cotula & 4 & ++ & - & - & 1 & ++ & 1 & + \\
\hline A. tinctoria & 4 & ++ & 4 & ++ & 7 & ++ & 5 & ++ \\
\hline A. sancti-johannis & 4 & ++ & 4 & ++ & 6 & ++ & 5 & ++ \\
\hline Chamaemelum nobile & 4 & $++b$ & 4 & $++b$ & 1 & $+b$ & 5 & ++ \\
\hline Chrysanthemum coronarium 'Big Leaf' & 4 & ++ & 4 & + & 5 & $++^{c}$ & 1 & + \\
\hline Tanacetum huronense & 4 & $+b$ & 4 & + & 6 & 0 & 5 & ++ \\
\hline T. parthenium & 4 & ++ & 4 & ++ & 5 & 0 & 5 & ++ \\
\hline T. vulgare & 4 & 0 & - & - & 1 & 0 & 4 & + \\
\hline Leucanthemum maximum & 4 & $++b$ & 6 & 0 & 1 & 0 & 5 & ++ \\
\hline L. vulgare & 4 & ++ & 4 & ++ & 2 & ++ & 3 & + \\
\hline Achillea millefolium ${ }^{\text {a }}$ & - & - & - & - & 1 & 0 & 3 & ++ \\
\hline A. ptarmica & 4 & 0 & - & - & 2 & 0 & 2 & 0 \\
\hline
\end{tabular}

${ }^{a}$ Test plant which was not accepted for oviposition by $D$. confluens in previous tests; ${ }^{b}$ only one larva found or adult emerged; ${ }^{c}$ only one replicate attacked. No-choice, offering one individual of a test plant species or control; single-choice, offering one test and one control plant simultaneously; multiple-choice, D. confluens: offering several test species and control plants simultaneously in field cages (1993 + 1995), and at field sites with either natural weevil density (1993) or augmented weevil density (1999); C. capucinus: offering several test species and control plants at field sites with natural weevil densities; ++, development to pupa or adult; +, development to mature larva; 0 , no development; -, not tested or replicates not valid.

Table 4. Levels of attack by Diplapion confluens on Matricaria recutita (herbal chamomile) and/or Tripleurospermum perforatum (target weed) plants in tests carried out at the CABI Bioscience Centre Switzerland, at natural field sites, or when collected from commercial herbal chamomile fields.

\begin{tabular}{|c|c|c|c|c|c|c|c|c|}
\hline \multirow{3}{*}{$\begin{array}{l}\text { Test type } \\
\text { Year }\end{array}$} & \multirow{3}{*}{$\begin{array}{c}\text { No-choice } \\
1997\end{array}$} & \multirow{2}{*}{\multicolumn{2}{|c|}{ Single-choice }} & \multirow{3}{*}{$\begin{array}{c}\text { Multiple-choice a } \\
1999\end{array}$} & \multicolumn{4}{|c|}{ Field host range } \\
\hline & & & & & \multicolumn{2}{|c|}{ Natural field sites } & \multicolumn{2}{|c|}{ Commercial fields of $M$. recutita } \\
\hline & & 1996 & 1998 & & 1994 & 1997 & $\begin{array}{l}\text { Switzerland } \\
1997+1998\end{array}$ & $\begin{array}{l}\text { Eastern Austria } \\
1997\end{array}$ \\
\hline $\begin{array}{l}\text { No. adults } \\
\text { released }\end{array}$ & $6-8$ & $8-10$ & $8-10$ & 10 & & & & \\
\hline $\begin{array}{l}\text { Exposure period } \\
\text { (in weeks) }\end{array}$ & 2 & 6 & 3 & 10 & & & & \\
\hline M. recutita & $\begin{array}{c}6.0 \pm 0.9 \\
(\mathrm{n}=4) \\
\text { n.s. }\end{array}$ & $\begin{array}{c}6.0 \pm 1.0 \\
(\mathrm{n}=2)\end{array}$ & $\begin{array}{c}11.0 \pm 7.1 \\
(\mathrm{n}=4) \\
\text { n.s. }\end{array}$ & $\begin{array}{c}63.6 \pm 17.7 \\
(\mathrm{n}=5) \\
* *\end{array}$ & $\begin{array}{c}3 \\
(n=80)\end{array}$ & $\begin{array}{c}1.0 \pm 0.4 \\
(\mathrm{n}=20)\end{array}$ & $\begin{array}{l}0(\mathrm{n}=10) \\
0(\mathrm{n}=20)\end{array}$ & $\begin{array}{l}0.2 \pm 0.1(\mathrm{n}=40) \\
0.4 \pm 0.1(\mathrm{n}=40)\end{array}$ \\
\hline T. perforatum & $\begin{array}{c}9.9 \pm 2.0 \\
(\mathrm{n}=17)\end{array}$ & $\begin{array}{c}37.5 \pm 10.5 \\
(\mathrm{n}=2)\end{array}$ & $\begin{array}{c}11.5 \pm 2.9 \\
(\mathrm{n}=4)\end{array}$ & $\begin{array}{l}9.1 \pm 2.0 \\
(n=10)\end{array}$ & $\begin{array}{c}16 \\
(\mathrm{n}=78)\end{array}$ & - & - & - \\
\hline
\end{tabular}

${ }^{a}$ Open-field test with augmented density of $D$. confluens. $n$, Number of replicates (no, single, and multiple-choice), or number of plants sampled (field host range); n.s., not significant; **, $P<0.01$.

Values given are the mean number of adults emerged per plant and/or larvae found upon dissection ( \pm SE), except for 1994, in which the total number of adults emerged is listed. For details of test conditions see Materials and methods. Differences in attack levels between $M$. recutita and T. perforatum were analysed using independent samples t-test (no-choice), dependent samples t-test (singlechoice), and Mann-Whitney U-test (multiple-choice).

\section{Discussion}

\section{Comparison of life history traits}

Diplapion confluens and C. capucinus are both univoltine root-mining weevils, as already stated by Dieckmann (1972). The fact that scentless chamomile grows mostly as a winter or summer annual in Europe, and plants usually set seed and start to dry up at the end of July, sets a natural limit to feeding and development in the roots. It is assumed that eggs laid in June are thus often wasted, because larvae are not able to complete development. Because D. confluens emerges in summer, females could theoretically lay eggs in 
late summer into winter rosettes of scentless chamomile, as is the case for the gall midge Rhopalomyia n. sp. (Hinz, 1998) or the agromyzid Napomyza sp. near lateralis (Fallén) (Diptera: Agromyzidae) (Hinz, 1999). Oviposition was, however, never observed in autumn. While weevils feeding on the roots of annual plants are generally univoltine, as for instance Mogulones geographicus (Goeze) and M. larvatus Schultze (Coleoptera: Curculionidae) on Echium plantagineum L. (Boraginaceae) (A. Sheppard, personal communication), below-ground herbivores on biennial or perennial plants may exhibit more flexible life histories exceeding one year (Müller, 1989; Blossey, 1993; Schwarzländer, 1997).

When C. capucinus emerges in spring, winter and/or summer rosettes of scentless chamomile are present. In contrast, it may be more difficult for $D$. confluens to locate adequate food sources after its emergence in summer, because biennial rosettes are not necessarily present, and winter rosettes only germinate in late summer or autumn. Thus, it is assumed that mortality of $D$. confluens adults after emergence in the field is higher than at the Centre, where weevils were constantly provided with fresh food. Greatest mortality in C. capucinus is assumed to occur during pupation and hibernation in the soil, due to predators, nematodes or entomophagous fungi (Brown \& Gagne, 1990). Soil disturbance during autumn, through cultivation, for instance, is thought to affect D. confluens less than C. capucinus, because it leaves the plants in summer and overwinters in the adult stage. This could be advantageous for establishment on periodically disturbed sites. The lower rates of parasitism of $D$. confluens compared to $C$. capucinus could be a result of larvae of $D$. confluens mining in the root crown and root from early instar onwards. They are thus more concealed than larvae of $C$. capucinus.

Females of $D$. confluens tended to lay more eggs than those of $C$. capucinus, and the average number of larvae in attacked plants was usually higher. However, larvae of C. capucinus mine for a longer time period and are larger in size than those of $D$. confluens. Therefore, they excavate larger mines, and may thus inflict more damage to the plant. In addition, the exophytic feeding of late instars of $C$. capucinus renders the roots vulnerable to secondary fungal attack. Coryssomerus capucinus females preferred larger plants for oviposition, and in both species attack was positively correlated with plant size. In early spring, eggs should therefore preferentially be laid into rosettes of scentless chamomile that have overwintered, and which at that time are larger than the later germinating summer rosettes (Hinz, 1999). Because winter rosettes are more competitive (Douglas et al., 1991) and usually have a higher reproductive output than summer rosettes (Hinz, 1999; A.S. McClay, personal communication), this should be advantageous for the successful control of this weed.

\section{Interspecific association}

In contrast to other guilds of phytophagous insect species that avoid direct competition by separation in space and/or time (Müller, 1989; Bacher, 1993; Forrester, 1993; Freese, 1995), mature larvae of D. confluens and C. capucinus showed high niche overlap within plants and utilized the plant during the same time period (figs 2 and 3). In addition, the two species occurred at most field sites together (table 2), and no negative interspecific association on individual plants could be detected. It has been suggested that a large overlap in resource utilization may actually indicate interspecific tolerance, whereas a small overlap may be a result of aggressive exclusion (Rathcke, 1976). The two chrysomelid beetles, Galerucella calmariensis (Linnaeus) and G. pusilla (Duftschmidt) (Coleoptera: Chrysomelidae), which also utilize the same temporal and spatial feeding niche on their host plant Lythrum salicaria L. (Lythraceae), co-exist in Europe despite frequent depletion of resources (Blossey, 1995). In an analysis of the phytophagous insect guilds associated with the roots of Centaurea spp. (Asteraceae), five distinct food niches were distinguished, each utilized by several insect species (Müller et al., 1989). However, most interspecific associations were random (Müller, 1989), possibly because attack levels of host plants were relatively low.

In contrast to parasitoids and predators used to control insect pests, for which rates of establishment have been shown to be inversely related to the number of species released (Ehler \& Hall, 1982), only little evidence exists for competitive exclusion of biological control agents used against weeds (Crawley, 1989; Briese, 1991). Even if competition occurs, a greater number of species usually seems to have a greater impact on the target weed on a population level (Harris, 1990; Müller-Schärer \& Schroeder, 1993; but see Myers, 1985).

\section{Host range}

Results of host-specificity tests conducted during this study confirmed, but also extended the host range recorded for $D$. confluens and C. capucinus in the literature (Dieckmann, 1972, 1977). Besides the host plants already noted, C. capucinus attacked in the field the medicinally used Chamaemelum nobile, the ornamental Leucanthemum maximum, the commercially grown Chrysanthemum coronarium L., and Tanacetum huronense, a plant species native to North America. The realized host range of $C$. capucinus is therefore considered to be too broad for introduction into North America.

The host range recorded for D. confluens, i.e. Matricaria spp. and Anthemis spp. (Dieckmann, 1977), was generally confirmed. The genus Tanacetum was only attacked in nochoice and single-choice tests, but not in multiple-choice tests under field cage or field conditions (table 3), whereas the limited development on Chrysanthemum coronarium 'Big Leaf' could not be anticipated by Dieckmann, because this species does not occur naturally in Europe. Leucanthemum vulgare was attacked when exposed in a field cage and a field test (see table 3), but was not found to be attacked when growing intermixed with scentless chamomile in the field, indicating that L. vulgare is probably not a normal field host of $D$. confluens.

Peschken et al. (1990) argued that M. recutita should be tested first in a screening programme for potential biological control agents, because it is very closely related to the target weed, and because it is used for medicinal purposes. Although, for the time being, $M$. recutita is not commercially grown in Canada, it may become a cash crop for North American farmers in the future (C. Richter, personal communication). Therefore, potential negative effects on this plant by introduced biocontrol agents for scentless chamomile were considered in more detail. Neither of the two weevil species is recorded as a pest of herbal chamomile or ornamental chrysanthemums in Europe (B. Aukema, F. Diefenbacher, A. Ellenberger, A. Kahrer, personal 
communication), and indeed, attack of commercially grown herbal chamomile by $D$. confluens was found to be very limited (see table 4). Because no alternative hosts, in particular, no T. perforatum, were present in the commercial fields, and these fields consisted of a large number of $M$. recutita plants, weevil densities (i.e. number of weevils per plant) were likely to have been low. In contrast, in the open field test, in which weevil numbers had been augmented, $M$. recutita was preferred over the target weed. It is unlikely, however, that the increase in weevil density alone caused this outcome, because similar numbers of weevils were used in no-choice and single-choice tests, in which $M$. recutita was attacked to the same or to a lesser degree than scentless chamomile (table 4). Differences in attack levels between the different tests thus remain difficult to explain. Our findings clearly indicate that it is important to test the host range of potential biocontrol agents under a variety of environmental conditions, particularly with augmented numbers, as are expected to occur after release (also see McFadyen, 1998 and Briese, 1999).

In conclusion, it was decided that the potential risk of $D$. confluens and $C$. capucinus to cultivated and native plants was too high, and anticipated impact too low (see Hinz, 1999) to justify release, and both species were therefore removed from the list of potential agents.

\section{Acknowledgements}

The authors thank A. Geisen, E. Gerber, T. Hunt, C. Kirkpatrick, K. Leiss and R. Pollard (all CABI Bioscience Centre Switzerland) for technical assistance, and C. van Achterberg (National Museum of Natural History, Leiden, Netherlands) and S. Vidal (University of Giessen, Germany) for identification of parasitoids. D. Matthies (University of Zürich, Switzerland), A. McClay (Alberta Research Council, Canada), D. Schroeder (CABI Bioscience Centre Switzerland) and two anonymous reviewers improved earlier versions of the manuscript. This project was funded by the Department of Environmental Protection, Province of Alberta, and the Department of Agriculture, Food and Rural Development.

\section{References}

Ali, S. (1995) Crop protection with chemicals. Agdex 606-1. Alberta Agriculture, Food and Rural Development, Edmonton, Alberta.

Alonso-Zarazaga, M.A. (1990) Revision of the supraspecific taxa in the Palaearctic Apionidae Schoenherr, 1823 (Coleoptera, Curculionidae). 2. Subfamily Apioninae Schoenherr, 1823: introduction, keys and descriptions. Graellsia 46, 19-156.

Bacher, S. (1993) Vergleichende ökologische Studien über zwei sympatrische Rüsselkäfer-Arten an der Geruchlosen Kamille (Tripleurospermum perforatum). Diploma thesis, University of Kiel, Germany.

Bacher, S. (1994) Die Strategien einer biologischen Bekämpfung der Geruchlosen Kamille in Kanada. Zeitschrift für Pflanzenkrankheiten und Pflanzenschutz, Sonderheft XIV, 221-230.

Blossey, B. (1993) Herbivory below ground and biological weed control: life history of a root-boring weevil on purple loosestrife. Oecologia 94, 380-387.

Blossey, B. (1995) Coexistence of two leaf-beetles in the same fundamental niche. Distribution, adult phenology and oviposition. Oikos 74, 225-234.

Briese, D.T. (1991) Current status of Agrilus hyperici (Coleoptera: Buprestidae) released in Australia in 1940 for the control of St. John's wort: lessons for insect introductions. Biocontrol Science and Technology 1, 207-215.

Briese, D.T. (1999) Open field host-specificity tests: Is 'natural' good enough for risk assessment? pp. 44-59 in Withers, T.M., Barton Browne, L. \& Stanley, J. (Eds) Host specificity testing in Australasia: towards improved assays for biological control. Indooroopilly, Scientific Publ.

Brown, V.K. \& Gange, A.C. (1990) Insect herbivory below ground. pp. 1-58 in Begon, M., Fitter, A.H. \& MacFadyen, A. (Eds) Advances in ecological research, Vol. 20. London, Academic Press.

Cole, D. (1994) Scentless chamomile: biology and control. Agdex 640-6. Alberta Agriculture, Food and Rural Development, Edmonton, Alberta.

Crawley, M. (1989) The successes and failures of weed biocontrol using insects. Biocontrol News and Information 10, 213-223.

Dieckmann, L. (1972) Beiträge zur Insektenfauna der DDR: Coleoptera - Curculionidae (Ceutorhynchinae). Beiträge zur Entomologie 22, 3-128.

Dieckmann, L. (1977) Beiträge zur Insektenfauna der DDR: Coleoptera - Curculionidae (Apioninae). Beiträge zur Entomologie 27, 7-143.

Douglas, D.W., Thomas, A.G., Peschken, D.P., Bowes, G.G. \& Derksen, D.A. (1991) Effects of summer and winter annual scentless chamomile (Matricaria perforata Mérat) interference on spring wheat yield. Canadian Journal of Plant Science 71, 841-850.

Douglas, D.W., Thomas, A.G., Peschken, D.P., Bowes, G.G. \& Derksen, D.A. (1992) Scentless chamomile (Matricaria perforata Mérat) interference in winter wheat. Canadian Journal of Plant Science 72, 1383-1387.

Ehler, L.E. \& Hall, R.W. (1982) Evidence for competitive exclusion of introduced natural enemies in biological control. Environmental Entomology 11, 1-4.

Ehret, J.M. (1990) Les Apions de France. Clés d'identification commentées (Coleoptera Curculionidae Apioninae). Bulletin Mensuel de la Société Linnéenne de Lyon 59, 209-292.

Forrester, G.J. (1993) Resource partitioning between two species of Ceutorhynchus (Coleoptera: Curculionidae) on Echium plantagineum in a Mediterranean habitat. Bulletin of Entomological Research 83, 345-351.

Freese, G. (1995) Structural refuges in two stem-boring weevils on Rumex crispus. Ecological Entomology 20, 351-358.

Harris, P. (1990) Feeding strategy, coexistence and impact of insects in spotted knapweed capitula. pp. 39-47 in Delfosse, E.S. (Ed.) Proceedings of the VII International Symposium on Biological Control of Weeds, 6-11 March 1988, Rome, Italy. Ist. Sper. Patol. Veg. (MAF), Rome, Italy.

Hinz, H.L. (1998) Life history and host specificity of Rhopalomyia n. sp. (Diptera: Cecidomyiidae), a potential biological control agent of scentless chamomile. Environmental Entomology 27, 1537-1547.

Hinz, H.L. (1999) Prospects for the classical biological control of Tripleurospermum perforatum in North America: population biology of the invader and interactions with selected insect herbivores. PhD thesis, University of Fribourg, Switzerland.

Hinz, H.L. \& Kirkpatrick, C. (1998) Investigations on potential biocontrol agents of scentless chamomile (Tripleurospermum perforatum (Mérat) Laínz). Unpubl. Annual Report, CAB International Institute of Biological Control, Delémont, Switzerland.

Hinz, H.L. \& McClay, A.S. (2000) Ten years of scentless chamomile: prospects for the biological control of a weed of cultivated land. in Proceedings of the X International 
Symposium on Biological Control of Weeds, 4-9 July 1999, Bozeman, Montana, USA (in press).

Lohse, G.A. (1983) Ceutorhynchinae. pp. 153-179 in Freude, H., Harde, K.W. \& Lohse, G.A. (Eds) Die Käfer Mitteleuropas, Vol. 11. Krefeld, Goecke und Evers.

McClay, A.S. (1989) Selection of suitable target weeds for classical biological control in Alberta. AECV89-R1. Alberta Environmental Centre, Vegreville, Alberta.

McFadyen, R.E.C. (1998) Biological control of weeds. Annual Review of Entomology 43, 369-393.

Müller, H. (1989) Structural analysis of the phytophagous insect guilds associated with the roots of Centaurea maculosa Lam., C. diffusa Lam., and C. vallesiaca Jordan in Europe: 1. Field observations. Oecologia 78, 41-52.

Müller-Schärer, H., Stinson, C.S.A., Marquardt, K. \& Schroeder, D. (1989) The entomofaunas of roots of Centaurea maculosa Lam., C. diffusa Lam., and C. vallesiaca Jordan in Europe. Niche separation in space and time. Journal of Applied Entomology 107, 83-95.

Müller-Schärer, H. \& Schroeder, D. (1993) The biological control of Centaurea spp. in North America: do insects solve the problem? Pesticide Science 37, 343-353.

Myers, J.H. (1985) How many insect species are necessary for successful biocontrol of weeds? pp. 77-82 in Delfosse, E.S. (Ed.) Proceedings of the VI International Symposium on Biological Control of Weeds, 19-25 August 1984, University of British Columbia, Vancouver, Canada. Agriculture Canada, Ottawa.
Peschken, D.P., Thomas, A.G., Bowes, G.G. \& Douglas, D.W. (1990) Scentless chamomile (Matricaria perforata) - a new target weed for biological control. pp. 411-416 in Delfosse, E.S. (Ed.) Proceedings of the VII International Symposium on Biological Control of Weeds, 6-11 March 1988, Rome, Italy. Ist. Sper. Patol. Veg. (MAF), Rome, Italy.

Peschken, D.P \& Sawchyn, K.D. (1993) Host specificity and suitability of Apion hookeri Kirby (Coleoptera: Curculionidae): a candidate for the biological control of scentless chamomile, Matricaria perforata Mérat (Asteraceae), in Canada. Canadian Entomologist 125, 619-628.

Rathcke, B.J. (1976) Competition and coexistence within a guild of herbivorous insects. Ecology 57, 76-87.

Schwarzländer, M. (1997) Bionomics of Mogulones cruciger (Coleoptera: Curculionidae), a below-ground herbivore for the biological control of hound's-tongue. Environmental Entomology 26, 357-365.

Southwood, T.R.E. (1978) Ecological methods. 524 pp. London, Chapman \& Hall.

Wagenitz, G. (1987) Nachträge, Berichtigungen und Ergänzungen zum Nachdruck der 1. Auflage von Band VI/2 (1928/9). in Hegi, G. (Ed.) Illustrierte Flora von Mitteleuropa, Spermatophyta, Band VI, Angiospermae, Dicotyledones 4. Paul Parey, Berlin, Hamburg.

Woo, S.L., Thomas, A.G., Peschken, D.P., Bowes, G.G., Douglas, D.W., Harms, V.L. \& McClay, A.S. (1991) The biology of Canadian weeds. 99. Matricaria perforata Mérat (Asteraceae). Canadian Journal of Plant Science 71, 1101-1119. 


\section{Appendix 1}

Test plant list for Diplapion confluens. For plant species also tested with Coryssomerus capucinus see table 3 . All plant species are in the family Asteraceae following the nomenclature of Wagenitz (1987).

\begin{tabular}{|c|c|}
\hline Plant species & Remarks \\
\hline \multicolumn{2}{|l|}{ Anthemideae } \\
\hline Tripleurospermum maritimum (L.) W.D.J. Koch & European species, introduced into North America \\
\hline T. ambiguum (Ledeb.) Franch. \& Sav. & Arctic species, native in North America and Europe \\
\hline Matricaria recutita $\mathrm{L}$. & Herbal/medicinal use, recorded as host of $D$. confluens in literature \\
\hline M. discoidea DC & $\begin{array}{l}\text { European weed introduced into North America, recorded as host of } D \text {. confluens } \\
\text { in literature }\end{array}$ \\
\hline Anthemis cotula L. & $\begin{array}{l}\text { European weed introduced into North America, recorded as host of D. confluens } \\
\text { in literature }\end{array}$ \\
\hline A. tinctoria L. & Ornamental, recorded as host of $D$. confluens and C. capucinus in literature \\
\hline A. sancti-johannis Stoy., Steff \& Turill & Ornamental, recorded as host of $D$. confluens in literature \\
\hline Chamaemelum nobile (L.) All. & Herbal/medicinal use \\
\hline Tanacetum cinerariifolium (Trev.) Vis. ${ }^{a}$ & Cultivated species ('pyrethrum') \\
\hline T. huronense Nutt. & Native in North America \\
\hline T. parthenium (L.) Schultz-Bip. & Ornamental, recorded as host of $C$. capucinus in literature \\
\hline T. vulgare L. & European weed introduced into North America \\
\hline Chrysanthemum carinatum Schousb. & Ornamental \\
\hline C. coronarium L. 'Big Leaf' & Cultivated species (vegetable) \\
\hline Leucanthemum maximum (Ramond) DC & Ornamental \\
\hline L. vulgare Lam. & $\begin{array}{l}\text { European species introduced into North America, recorded as host of } C \text {. capucinus } \\
\text { in literature }\end{array}$ \\
\hline Artemisia cana Pursh. ${ }^{\mathrm{a}}$ & Native in North America \\
\hline A. frigida Willd. ${ }^{\mathrm{a}}$ & Native in North America \\
\hline A. ludoviciana Nutt. ${ }^{a}$ & Native in North America \\
\hline A. vulgaris L. ${ }^{\mathrm{a}}$ & European weed introduced into North America \\
\hline Achillea filipendulina Lam. ${ }^{\mathrm{a}}$ & Ornamental \\
\hline A. millefolium L. ${ }^{\mathrm{a}}$ & $\begin{array}{l}\text { Native in Europe and North America, recorded as host of C. capucinus in } \\
\text { literature }\end{array}$ \\
\hline A. ptarmica L. & European species introduced into North America \\
\hline Dendranthema indica (L.) ${ }^{\mathrm{a}}$ & Wild progenitor of cultivated chrysanthemums \\
\hline D. grandiflora Tzvelev, varieties ${ }^{\mathrm{b}}$ & Cultivated varieties \\
\hline \multicolumn{2}{|l|}{ Heliantheae } \\
\hline Ratibidia columnifera (Nutt.) Wootton \& Standl. ${ }^{a}$ & Native in North America \\
\hline Rudbeckia hirta L. & Native in North America, cultivated as ornamental \\
\hline Helianthus annuus L. ${ }^{\mathrm{b}}$ & Cultivated species \\
\hline H. annuus sp. lenticularis (Lindl.) Cockerell ${ }^{\mathrm{b}}$ & Wild progenitor of cultivated sunflower \\
\hline H. nuttallii Torr. \& Gray ${ }^{\mathrm{a}}$ & Native in North America \\
\hline \multicolumn{2}{|l|}{ Astereae } \\
\hline Erigeron annuus (L.) Pers. ${ }^{a}$ & Native in North America \\
\hline E. caespitosus Nutt. ${ }^{\mathrm{a}}$ & Native in North America \\
\hline Grindelia squarrosa (Pursh.) Dunal ${ }^{\mathrm{a}}$ & Native in North America \\
\hline Aster laevis L. ${ }^{\mathrm{a}}$ & Native in North America \\
\hline A. novae-angliae L. ${ }^{\mathrm{a}}$ & Ornamental \\
\hline \multicolumn{2}{|l|}{ Senecioneae } \\
\hline Senecio eremophilus Richards ${ }^{\mathrm{a}}$ & Native in North America \\
\hline S. vulgaris L. ${ }^{\mathrm{a}}$ & Weed in Europe and North America \\
\hline \multicolumn{2}{|l|}{ Cynareae } \\
\hline Cirsium arvense (L.) Scop. ${ }^{\mathrm{a}}$ & European weed introduced into North America \\
\hline \multicolumn{2}{|l|}{ Cichorieae } \\
\hline Lactuca sativa L. $^{\mathrm{a}}$ & Cultivated species \\
\hline Taraxacum officinale L. ${ }^{a}$ & European weed introduced into North America \\
\hline
\end{tabular}

aNot accepted for oviposition by D. confluens; bno signs of larval mining by $D$. confluens found. 